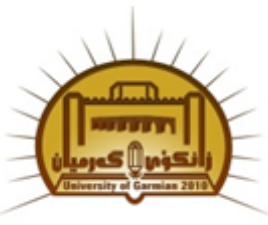

Available online at http://jgu.garmian.edu.krd

Journal of University of Garmian

https://doi.org/10.24271/garmian.196362

\title{
After-effect of War on Characters in Ernest Hemingway's "Soldier's Home" and Katherine Mansfield's "The Fly"
}

\author{
Snoor Ismael Mahmood \\ Department of English, College of Education, University of Garmian
}

\section{Article Info}

Received: August, 2019

Revised:August,2019

Accepted:September,2019

\section{Keywords}

After-effect of War, World War I, Trauma, Inner psych of characters, "Soldier's Home", "The Fly".

Corresponding Author

Dlpak.jabar@garmian.edu.krd

\section{Abstract}

This paper tries to explore the representation of the First World War and its lingering effects on the life of people in two different modern short stories. The stories are written by different modern writers: The first story is entitled Soldier's Home. It is written in1924 by a male American writer Ernest Hemingway who witnessed several great wars such as World War I and World War II. The Second short story is entitled The Fly. It is written in 1922 by a female writer from New Zealand, Katherine Mansfield who lost her brother in World War I. The study compares the after effect of war on characters in these two different short stories. It focuses on how the war shapes the life of characters even after it ends. It shows how different characters struggle to cope with the trauma, stress and psychological pressure inflicted on them due to the violent experience of war. It also shows how war plays a destructive role in the life of combatants and non-combatant. The study sums up that both writers represent the horror and dark side of war and its destructive power on post-war generation through the brutal effects on the life of characters.

\section{Introduction}

Ernest Hemingway (1899-1961) is one of the modern American writers whose personal experience has become a basement for his literary achievements that captured the reality of his age. What he witnessed throughout his life, from early childhood outdoor activities to different experiences of journalism, traveling, adventures, bloody battles, death, and violence have been an abiding element of his writings. His career as a writer started from writing an article for the school newspaper The Trapeze. After high school, he became a reporter for
Kansans City Star. His experience as a reporter shaped his style of writing as he was taught the exactness and style of writing. There he was directed to "use short sentences. Use short first paragraphs. Use vigorous English. Be positive, not negative." (Guion 4).

From his early adulthood until he died he was interested in dangerous activities and adventures. He was a participant in different wars. First, he joined the Italian army as an ambulance driver in World War I and he was wounded while he was 18 years old. Then he transferred the scenes of Greek armies retreat 
from Constantinople in 1922 for Toronto Star newspaper. He also reported the scenery of the Spanish civil war for the North American newspaper in 1937-38. He also worked as a reporter for Mp magazine in 1941 and reported war events of the China war with Japan. During the Second World War, he was a reporter reporting the conditions of the combat area. Throughout his life, he survived different dangerous accidents such as a car accident and an airplane crash (Oliver 3).

While Katherine Mansfield is a modern writer from New Zealand born in 1888 and died because of tuberculosis in 1923. She is a famous short story writer and a poet who was from a prosperous ancestor. Her father was a bank director. Her mother suffered from heart disease and died in 1918 (Meyers 3- 7) the loss of her mother made her suffer psychologically. In addition to that, the most traumatic event in her life was the death of her younger brother in World War I in 1914. According to a biographer, Antony Alpers, the loss of her brother lead to her health decline and physical sickness of tuberculosis in 1917. He argues that the traumatic effect of war and personal loss has left her in a state of deep psychological suffering (Morrow 39). Her personal experience enables her to write short stories that are concerned with human thoughts of alienation, loneliness, behavior and social and familial issues of that time. She portrayed the character with deep inner thoughts and dreams. As it has been remarked by Julia van Gunsteren, the different psychological states of different characters have been depicted in her short stories including "Innocent children, initiated woman, afflicted mother, reconciled grandmother, to energetic businessman" who are suffering from alienation and loneliness(174).

These two different writers from different social backgrounds and common experiences of the effect of World War I are highlighting the effect of traumatic experience of war on the characters in their short stories. In this research, an attempt has been made to compare the dark side and aftermath of the war in these two different short stories. The first short story by Earnest Hemingway depicts a character who has survived war, Krebs, who is the main character of the story, he is an American soldier. He returns to Oklahoma after the end of World War I. He survives the war but the war has affected him in a way he cannot connect with his surroundings and even his mother. They try to involve him with his surrounding but it is useless. He is an outsider within the community and he cannot lead a normal life at the end he leaves his Oklahoma to find a job in Kansas City and lead a normal life.

Meanwhile, Katherine Mansfield in her short story "The Fly", deals with the after effect and the dark side of war on the remaining member of the family of those who are killed in the war. The sons of the Boss who is the main character in the short story and his friend Mr. Woodifield, have been killed in the World War I. Mr. Woodifield is an old man. He pays a visit to his friend's bank. He suffers from heart disease. They have a conversation together. The boss has kept the photo of his son in the office that reminds him of his son. Mr. Woodifield also mentions that his daughters visited the grave of their sons. After Mr. Woodifield's departure the Boss is preoccupied by his thought then he drops ink on a fly and watches the struggle of the fly till it dies. He feels melancholic and miserable. Comparing these two short stories the after mass of war is shown through the characterization of the protagonists of both stories.

\section{War in "Soldier's Home"}

Ernest Hemingway in his short story "Soldier's Home" writes about the effect of war by depicting a character that is psychologically depressed. He does not explicitly depict the image of the battlefield but shows the aftereffect and destructive power of war that linger in the life of those who have survived. He shows 
the painful realities of wartime experience and its lasting effect on the post war generation. The story starts with the movement of a solider to war and a simple description of two photos that give the reader an insight into the life of the central character before and after the war.

Krebs went to the war from a Methodist college in Kansas. There is a picture which shows him among his fraternity brothers, all of them wearing exactly the same height and style collar. He enlisted in the Marines in 1917 and did not return to the United States until the second division returned from the Rhine in the summer of 1919.

There is a picture which shows him on the Rhone with two German girls and another corporal. Krebs and the corporal look too big for their uniforms. The German girls are not beautiful.(Hemingway 1)

Before moving to war, he was, like other boys, studying at school, and he was from a Methodist college. He was leading a normal life with determined goals to achieve. As it has been argued, by Lewis, that "Methodist college" denotes "order and stability" in the life of Krebs before the war (175). The second photo gives the reader a scene from the battlefield of World War I. Being a soldier in the frontlines and due to the traumatic effect of war, when he returns home, Krebs cannot live a normal life as he used to live before the war. As Robert Paul Lamb remarks in the second photo, their bodies are described as a "too big" which suggests the influence of war on Krebs' life. As a consequence of the violent experience of war, he has become more "individualistic and grown"(21). When he comes back, he is a numbed person; he cannot reestablish a connection with his family members, society, and other soldiers. $\mathrm{He}$ is depressed to the extent that as if he is an outsider. He hardly can adjust himself to his surroundings.

He sleeps late, he walks around the town aimlessly, eats, sleeps, he is sleepy-head. He does not have love for anything and anyone even God. He practices some kind of sport and watches the girls from their porch. As the narrator says:

During this time, it was late summer, he was sleeping late in bed, getting up to walk down town to the library to get a book, eating lunch at home, reading on the front porch until he became bored and then walking down through the town to spend the hottest hours of the day in the cool dark of the pool room. He loved to play pool (Hemingway 2)

Hemingway conveys that even those who have survived their life have been destroyed by war and even the war was over but still it affects people destructively. After one year of ceasing the war, this young soldier feels alienated from his surroundings. $\mathrm{He}$ is lethargic, he continuously feels sleepy, fatigued, and sluggish. He has become an apathetic individual; he has no concern, interest, passion, and motivation for leading an active and normal life. He passively watches the girls and sees them as a work of art but he is not interested in establishing a romantic relationship and being settled down with one of them.

$\mathrm{He}$ is broken and suffers from depression. He just loved to play pool, and sometimes practiced his clarinet rather than being involved in managing a business. The games are presented as psychosocial support activities to heal the pain that he goes through. It is like a therapeutic aid for recovering. The pool room helps him to escape from his life and find comfort for a while. It prevents him from recalling the horror of the war. It stands as an attempt to restore order in his life.

$\mathrm{He}$ is crippled by the war in a way he cannot even connect with his mother and even say a prayer. When Krebs' mother asks him if he loves her, he responds, "I don't love anybody." He also declares that he cannot pray. He has lost hope in God and feels disabled to connect with him. He says "I am not in His Kingdom" He 
"felt embarrassed and resentful as always" (Hemingway 6). Due to the terrific effect of the war, he is always silent and angry. Accordingly, Arthur Waldhorn describes Krebs as been "shocked into a psychic disorientation" under the horrible experience of war. He further remarks that Krebs' "silence is a wordless metaphor expressing outrage against the chaos of the universe and the isolation of the individual" (qtd. In Lamp 63 )

Throughout the story, the writer confirms that it's the effect of war that has shaped his current psychological state. As the writer shows that before the war he wanted to derive the car and get out with girls. This is implicitly shown in his mother's effort to make him return to his previous state. His mother comes into his bedroom one morning to inform Krebs that his father has decided to allow him to drive the car and even encourages him to get out with girls. Krebs replies in a cynical manner saying "I'll bet you made him." (Hemingway 3-4)

Although he is physically safe, he is traumatized emotionally and destroyed psychologically. It cost him to lose the sense of himself as an active human being. The estrangement of the mood of this soldier stands as an embodiment for those soldiers who were in the frontlines of war. As argued by David M. Lubin, "Krebs exemplifies a widespread reluctance- if not downright inability- on the part of AEF veterans to communicate their frontline experiences to those who had not left home." (247).Similarly, the title of the story alludes to the thematic concern of the story since we have "soldier's home", not Krebs's home. The phrase soldier's home signifies "arrest home for severely wounded veterans or a refuge for indigent former soldiers" (Becnel 270). The story depicts the "uncomfortable realities of his age and forces into public consciousness a realization of the brutalities of war and their lingering psychological effect." (Gates qtd. in Putman 7).
The corruption of war has been shown in the depiction of other characters who take their share of the devastating effect of war; like the family members of the soldier. They exemplify the members of the society who have been affected by war even though they were not the participant of the war. The effect of war extends to all members of society. This has been shown in the familial relationship of Harold Krebs. His mother is affected by the psychological state of his son. She continuously tries to support her son psychologically. She feels pity, and sentimentally she is hurt when she feels powerless about the state of her son. She feels like she has lost her son and tries continuously to bring him back to a state of emotional and adulthood independence as any settled young boy. When she finds her attempt as useless she collapses psychologically and falls in tears. She feels that war has put his son in an irrevocable condition: as she says:

"I've worried about you too much, Harold," his mother went on. "I know the temptations you must have been exposed to. I know how weak men are. I know what your own dear grandfather, my own father, told us about the Civil War and I have prayed for you. I pray for you all day long, Harold."

"Your father is worried, too," his mother went on. "He thinks you have lost your ambition, that you haven't got a definite aim in life. Charley Simmons, who is just your age, has a good job and is going to be married. The boys are all settling down; they're all determined to get somewhere; you can see that boys like Charley Simmons are on their way to being really a credit to the community."

Krebs said nothing (Hemingway 6).

The father too, who finds the success of his son's life in the field of business and having a job, he feels disappointed that his son has lost his ambition and interest in depending on himself materialistically. For the father also his son is lost, since the son bluntly detaches himself from 
social life and his community. His sister also feels like she has lost his brotherhood because of war; since the boy is not interested in establishing any jovial brotherly relationship with her.

"Will you come over and watch me play indoor?" "Maybe." "Aw, Hare, you don't love me. If you loved me, you'd want to come over and watch me play indoor." (Hemingway 5)

Krebs does not seem to be interested. $\mathrm{He}$ is alienated or rather his experiences had alienated him from his surroundings. The story ends with the main character's effort to find a job and passing by her sister and watching her. He tries to move forward. The glories of war are described as hypocritical and corrupt and absurd. The continuing depressed mood of the main character shows the frustration against war and its devastating effect.

\section{War in "The Fly"}

Katherine Mansfield in her short story the fly sheds light on the effect of war on people. When she wrote the fly in 1922, she tried to show the catastrophic effect of war on individual human beings in a time when people were suffering from the aftermath of the horror of the brutal war. It is assumed that the story shows the "brutal horror of World War I along with the hopelessness and despair left in its wake.". ( Fahim \& Akbari 164). During the war, people are affected differently, by personal loss, death of beloved and the death and injury of the soldiers whether that is physical or psychological.

In "The Fly", she shows the traumatic influence of war through the tragedy of personal loss; as it has been exposed in the portrayal of the characters in the story. For this purpose, the writer has shifted her focus on the thought and interior world of the character to help the reader evocate the chaotic reality of after wartime. Therefore, the plot of the story is rather an arrangement of scenes that expose the inner psyche of the character rather than the events of the battlefield. The scenes make us conceptualize the horror of the battlefield and its aftereffect on the generation after World War I. The story starts with a conversation at an office between Mr. Woddifield and his former employer and friend, named the Boss, six years after the war. The sons of both of them have been killed in World War I. The effect of the war has been shown in the depiction of an old man who suffers from a stroke. Stroke is a kind of disease that is associated with psychological disorders such as anxiety, frustration, and depression; this can be analyzed as a manifestation of suffering and pain caused by the death of his son in the war. The narrator describes Mr. Woodifield in the passage below, as a person who needs care.

"since his ... stroke, the wife and the girls kept him boxed up in the house every day of the week except Tuesday. On Tuesday he was dressed and brushed and allowed to cut back to the City for the day." (Mansfield 158)

$\mathrm{He}$ is a victim of stroke and embodies the emotional turmoil that renders in the psyche of human beings. The conversation between them shows the effect of war that continued, six years after the war, to torture the father of the martyrs of the war. Through the portrayal of the suffering of these fathers, the writer shows the dark side of war and criticizes the authorities who are responsible for the initiation of war and the death of the people.

The writer tries to show the brutality of war through image, and depiction of the psychological states of the main characters .

But he did not draw old Woodifield's attention to the photograph over the table of a grave-looking boy in uniform standing in one of those spectral photographers' parks with photographers' stormclouds behind him. It was not new. It had been there for over six years. (Mansfield 159)

Here, the picture of the dead son of the Boss in the office of his father stands as a vehicle that 
highlights the effect of war. The existence of the photo services as a reminder of the aftermath of war and the lingering of wars' torturing effect after six years. It shows how several families in London suffer because of the loss of the members of their families; this idea has been reinforced by the visit of the father of another young man, who is killed also in the war, especially when Mr. Woodifield mentions that her daughter has visited the grave of their brother.

'I thought you'd like to know. The girls were in Belgium last week having a look at poor Reggie's grave, and they happened to come across your boy's. They're quite near each other, it seems.'

Old Woodifield paused, but the boss made no reply. Only a quiver in his eyelids showed that he heard.(Mansfield 160)

So the writer shows the dark side of war and its effect that resulted in a human loss for the dead soldiers and suffering for those who are alive like the fathers, sisters, brothers, and mothers of the martyrs. For Katherine war changed everything, it separated her from her family member and friend as her brother and friend were killed in the war. As she states:" I cannot imagine how after the war these men can pick up the old threads as though it never had been... I would say we have died and live again." (Kimber 78). The scenes of the story give the reader a lens to see the aftermaths of war and the darkness that it cast over people's lives.

The above example also reminds the boss of his lingering mental suffering because of the loss of his son. He lives in a state of disillusionment and psychological collapse despite his success as a bank manager. The writer shows us the image of the boss's office followed by the image of his son. She wants to show that the war has disappointed the father who planned a great fortune for the future of his son. As the narrator states: "His boy was an only son. Ever since his birth, the boss had worked at building up this business for him; it had no other meaning if it was not for the boy. Life itself had come to have no other meaning."(Mansfield 161)

After the departure of his friend he stays motionless and looks at nothing.

For a long moment the boss stayed, staring at nothing, while the grey-haired office messenger, watching him, dodged in and out of his cubbyhole like a dog that expects to be taken for a run. Then: 'I'll see nobody for half an hour, Macey,' said the boss. 'Understand! Nobody at all.' 'Verygood,sir.'

The door shut, the firm heavy steps recrossed the bright carpet, the fat body plumped down in the spring chair, and leaning forward, the boss covered his face with his hands. He wanted, he intended, he had arranged to weep....(Mansfield 161).

The narrator describes the state of his mind that gives a reader a comprehensive insight into the anguish of the father who has lost his son. The description is like an expository of the internal thought and feeling of a groaning soul:

It had been a terrible shock to him when old Woodifield sprang that remark upon him about the boy's grave. It was exactly as though the earth had opened and he had seen the boy lying there with Woodifield's girls staring down at him. For it was strange. Although over six years had passed away, the boss never thought of the boy except as lying unchanged, unblemished in his uniform, asleep for ever. "My son!" groaned the boss. But no tears came yet. In the past, in the first months and even years after the boy's death, he had only to say those words to be overcome by such grief that nothing short of a violent fit of weeping could relieve him. Time, he had declared then, he had told everybody, could make no difference. (Mansfield 161)

The narrator then mentions the day of receiving the news of killing his son. Although time has passed, the father is still broken with his life in ruins. The grief is just like, it might have happened yesterday. 
In addition to the photo, the writer uses the title scene of the fly to shows the picture of the brutality of battlefields and the struggle of involved people. In which the soldiers are fighting and trying to keep themselves safe, the struggle of the fly shows the effort of soldiers in the frontlines of war who fight and fight and escape once twice till in the end they die. The old man can be seen as the leader that supports war regardless of the effect of war. It also visualizes the anguish of those like the boss who is suffering because of the damaging consequences of the war. The fly can be a symbol of a torturing soul that wants to fly to the sky and get rid of or survive his suffering with courage. Accordingly, Dan Shen in his book Style and Rhetoric of Short Narrative Fiction argues that "the boss increasingly identifies with the fly" (135)

At that moment the boss noticed that a fly had fallen into his broad inkpot, and was trying feebly but desperately to clamber out again. Help! Help! said those struggling legs. But the sides of the inkpot were wet and slippery; it fell back again and began to swim. (Mansfield 162) In the scene, the fly is personified with expressions of "help! Help !", this alludes to the struggle of human beings while they are in the middle of turmoil like the battlefield or the psychological suffering. He struggles for survival. He survives once and twice and tries to overcome his miserable state and to be ready for life again. As Dan Shen states "when the boss sees the fly about to be drowned in the drop of ink, the inner thought of the boss is exposed in free indirect speech" What would it make of that" "What indeed" he admires the effort of the fly to surpass his situation. Saying "That was the way to tackle things; that was the right spirit. Never say die.." These look like a motivating statement to soothe the suffering of the boss (135).

The central character sees himself as the fly. His game of dropping ink on the fly "evokes an attempt to master trauma- the loss of his son in the war, his consequent lack of purpose, and his complicity in the forces behind the war." (Kimber 103) The fly's attempt to escape evokes an individual's effort to escape from an anguished soul. It indicates the desire to transcend his physic torture.

The little beggar seemed absolutely cowed, stunned and afraid to move because of what would happen next. But then, as if painfully, it dragged itself forward. The front legs waved, caught hold, and, more slowly this time, the task began from the beginning (Mansfield 162).

In this sense, the feeling of anxiety, stress, frustration, pessimism, violence, and endurance are exposed to the reader through the image of the fly. The fly is trapped like a man due to the bitterness of after war life. The story ends with the killing of the fly and thinking of the Boss he forgot what he was thinking about: "What was it? It was... He took out his handkerchief and passed it inside his collar. For the life of him he could not remember." (Mansfield 163) The scene of the fly can be regarded as a kind of play for the Boss to forget recalling the bitter memory of war. The war has inflicted a reality on the generation that let them alienated, disillusioned, and collapsed psychologically. They need to be sharp to survive it. As the boss says "come on, be sharp! (Mansfield 163).

\section{Conclusions}

As a result, the study has identified several similarities in "Soldier's Home" by Ernest Hemingway and "The Fly" by Katherine Mansfield. Both of them write about the influence of war on people. They do not directly write about war by describing and picturing the battlefield or frontline area. They write about the post-war life of people through the depiction of characters that show the human condition in the aftermath of war. "Soldier's Home", as the title suggests, shows the destructive effect of war on the life of those who were combatant and 
survived. "The Fly" further shows the effect of war on non-combatants who lost their sons, friends, and relatives in the war and how war continues to affect their lives negatively.

Ernest Hemingway uses a photo as a device for predicting the brutality of war in the mind of the reader. Similarly, Katherine Mansfield uses the photo of the killed son in his father's office as a device for showing the lingering effect of war on the life of people. When the father looks at the photo of his son he transcends to a world of alienation and psychological suffering and hopelessness. The photos in both stories also serve as a kind of comparing the life of these characters before and after the war.

The moods of the main characters are the same in both of the short stories. The main character Harold Krebs is depressed, alienated, bewildered wanders aimlessly and joylessly he is not willing to build a connection with others within the society. Even the mothers and other members of the family are affected by the temper of their son. In a way, the mother starts to cry. In the same way, the main character of "The Fly", the Boss, is depressed, isolated is unwilling to be disturbed by anyone in his office. $\mathrm{He}$ is disgruntled, distressed, unsatisfied because of the loss of his son. He wants to weep whenever the memory of his son is recalled in his mind. The characters of both stories are in a continuous struggle to cope with the reality of their time that is cast on them because of the effect of war.

\section{Woks Cited}

1. Becnel, Kim E. Bloom's How to Write about Ernest Hemingway. New York: Bloom's Literary Criticism, 2009. Print.

2. Fahim, Mansoor \& Mahnaz Akbari. Short Stories for Critical Analysis. Tahran: Rahnama Press, 2008. Print.

3. Guion, Payton. Ernest Hemingway: A Biography. Np.: Hyperink, 2012. Print.
4. Gunsteren, Julia Van. Katherine Mansfield and Literary Impressionism. Amsterdam: Rodopi, 1990. Print.

5. Hemingway, Earnest. "Soldier's Home"( 1925),

http://www.somanybooks.org/eng208/Soldiers Home.pdf

6. Kimber, Gerri. Katherine Mansfield and the Art of Short Story. New York: Palgrave, 2015. Print.

7. Lamp, Robert Paul. The Hemingway Short Story: A Study in Craft for Writers and Readers. Louisiana: Louisiana State University Press, 2013. Print.

8. Lewis, Robert W., Jr. "Hemingway's Concept of Sport and 'Soldier's Home." The Short Stories of Ernest Hemingway Critical Essays, edited by Jackson J. Benson, Duke UP, 1975, pp. 170-80.

9. Lubin, David M. Grand Illusions American Art and the First World War. Oxford: Oxford University Press, 2016. Print.

10. Mansfield, Katherine. "The Fly". Short Stories for Critical Analysis. Mansoor Fahim \& Mahnaz Akbari. Rahnama press, 2008,pp.153163.

11. Meyers, Jeffrey. Katherine Mansfield: A Darker View. New York: Cooper Square Press, 2002. Print.

12. Morrow, Patrick. "Katherine Mansfield and World War I" Literature and War. Ed. By David Bevan. Amsterdam: Rodopi, 1990, PP.39-44.

13. Oliver, Charles M. Critical Companion to Ernest Hemingway: A Literary Reference to His Life and Work. New York: Facts on File, 2007. Print.

14. Putman, Thomas. " Hemingway on War and its Aftermath" Prologue Magazine, Vol. 38, No. 1, $\quad$ spring, 2006.< https://www.archives.gov/publications/prologu e/2006/spring/hemingway.html

15. Shen, Dan. Style and Rhetoric of Short Narrative Fiction: Covert Progression behind Overt Plots. New York: Routledge, 2104. Print 